\title{
CANTINELA INFANTIL Y RIMAS EN EL TEATRO DE FEDERICO GARCÍA LORCA
}

\section{CHILDREN SONGS AND RHYMES IN THE THEATER OF FEDERICO GARCÍA LORCA}

\section{COMPTINES ENFANTINES ET RIMES DANS LE THÉÂTRE DE FEDERICO GARCÍA LORCA}

\author{
MARÍA Victoria Utrera TORREMOCHA \\ Universidad de Sevilla
}

Resumen: Se estudia en este trabajo la cantinela infantil en el teatro de Federico García Lorca. El artículo muestra la importancia de ciertos recursos de repetición entre los que la rima se revela como procedimiento rítmico unificador de la heterometría y del aparente sinsentido. Puede hablarse, por lo tanto, de rima hilada, creadora y generatriz del sentido poemático.

Palabras clave: cantinela infantil, rima hilada, teatro, Federico García Lorca.

Abstract: The aim of this study is to analyze the children's song in the theater of Federico García Lorca. The article shows the importance of certain repetition resources among which the rhyme reveals to be a unifying rhythmic procedure of heterometry and apparent nonsense. We can speak, therefore, of an extended rhyme, creator and generator of the poetic sense. 
Keywords: children song, extended rhyme, theater, Federico García Lorca.

Résumé: La ritournelle enfantine dans le théâtre de Federico García Lorca est étudiée dans le présent travail. L'article montre l'importance de quelques procédés de répétition, parmi lesquels la rime apparaît comme l'élément rythmique unificateur de l'hétérométrie et du non-sens apparent. On peut donc parler de rime filée, créatrice et génératrice du sens poématique.

Mots-clés: comptine, rime filée, théâtre, Federico García Lorca. 


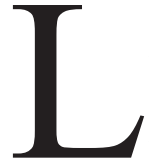

a presencia de las canciones populares es un rasgo identificador de la tradición poética hispánica. Concretamente en ciertos autores es evidente esta peculiar simbiosis entre música, fórmulas orales, poesía popular y poesía culta. Es el caso de Federico García Lorca, que reproduce, adapta y recrea poemas y formas populares.

En sus conferencias Lorca pone de manifiesto una y otra vez la verdad profunda de los ritmos populares. Se trata de una verdad emparentada con lo sublime, la muerte y el misterio y que se revela en el cante jondo y en otras clases de canciones enraizadas en el pueblo, concepción que aparece claramente en varios escritos del poeta y muy especialmente en «Juego y teoría del duende». El poeta con duende es el poeta musical de lo escondido, sin normas, que rompe los estilos y se apoya en el dolor y en la emoción profunda: «La llegada del duende presupone un cambio radical en todas las formas ${ }^{1}$. La música, la danza y la poesía hablada serían las artes en las que el duende se revela mejor, porque son artes vivas ${ }^{2}$.

Prácticamente en toda la obra lorquiana es patente el influjo de la poesía oral. En algunos casos, la presencia de la canción popular anónima se inserta de forma directa en su obra, total o parcialmente. En otros casos, el autor granadino reelabora personalmente las canciones del pueblo para adaptarlas a un nuevo marco. Su interés por este tipo de composiciones está ampliamente reconocido por parte de toda la crítica especializada. No hay que olvidar, por otra parte, su formación como músico, su afición a cantar al piano cancioncillas populares y su labor de recogida de canciones orales anónimas ${ }^{3}$.

${ }^{1}$ García Lorca, Federico, «Juego y teoría del duende», en Conferencias, vol. II, introducción, edición y notas de Christopher Maurer, Madrid, Alianza, 1984, p. 97.

${ }^{2}$ Ibid., pp. 98-99.

3 Véase, por ejemplo, García Lorca, Francisco, Federico y su mundo, edición de Mario Hernández, Madrid, Alianza, 1980, p. 335; MAURER, Christopher, «Lorca y las formas de la música», en Andrés Soria Olmedo (ed.), Lecciones sobre Federico García Lorca, Granada, Comisión Nacional del Cincuentenario, 1986, pp. 235-250; MARTíneZ NADAL, Rafael, Cuatro lecciones sobre Federico García Lorca, Madrid, Fundación 
De acuerdo con el Diccionario de la Real Academia Española de la Lengua, la cantinela es «una composición poética breve, hecha generalmente para que se cante». En la segunda acepción del término, se señala que cantinela es «repetición molesta e importuna de algo». En esta segunda acepción se aprecia la importancia del elemento rítmico y la connotación de un ritmo molesto o de sonsonete. Conviene recordar que el término latino posee también este valor significativo de reiteración y oralidad, al significar 'estribillo' y también 'habladurías'. No resulta raro entonces que la cantinela se haya usado muchas veces para designar la canción infantil cantada, y no solamente por sus obvios componentes rítmicos y musicales, sino también por el carácter fastidioso de un tipo de ritmo asociado a la recurrencia continuada.

José Domínguez Caparrós señala también varias acepciones para el vocablo. Además de designar un cantar, la palabra tiene un significado que entronca directamente con nuestra mejor tradición métrica popular. Así, cantinela sería aquel «poema formado por una sola estrofa breve (cuarteta, seguidilla, redondilla, soleá...)». Se trata de un tipo de canción popular que «también se emplea en la poesía culta del siglo XX que se inspira en la poesía de tipo popular» ${ }^{4}$.

Nos centraremos en este trabajo particularmente en algunas cancioncillas de acento infantil en las obras teatrales de Lorca. Dejamos de lado, por tanto, aquellas composiciones que prescinden del aire de juego por más que sean de gran relevancia en la obra lorquiana. La práctica totalidad de estas obras lorquianas contiene cantinelas. Estas son más frecuentes en las primeras obras del

Juan March-Cátedra, 1980, pp. 17 y ss. Daniel Devoto ha estudiado la presencia de la canción tradicional en la obra lorquiana, destacando algunas de sus fuentes y los procedimientos más característicos en «Notas sobre el elemento tradicional en la obra de García Lorca» (1950), en Ildefonso-Manuel Gil (ed.), Federico García Lorca, Madrid, Taurus, 1989, pp. 23-72. Por su parte, dentro del teatro y sobre todo en el estudio de Mariana Pineda, Fernando LÁzARo CARreter señala la importancia en el autor granadino del contacto con el pueblo mediante las «formas poéticas ingenuas y populares» («Apuntes sobre el teatro de García Lorca», en Ildefonso-Manuel Gil (ed.), Federico García Lorca, cit., p. 339. Véase también De Onís, Federico, «Lorca, folklorista» (1940), en La música en la generación del 27. Homenaje a Lorca, Madrid, Ministerio de Cultura, 1986, pp. 84-88; Greenfield, Sumner M., «El problema de Mariana Pineda», en Ildefonso-Manuel Gil (ed.), Federico García Lorca, cit., pp. 371-382; Canciones del teatro de García Lorca, revisión de Gustavo Pittaluga, Madrid, Unión Musical Española, 1966; Assumma, María Cristina, «Lo propio y lo ajeno en Federico García Lorca», Paremia, 18 (2009), pp. 99-109; Fuentes, Tadea, El folklore infantil en la obra de Federico García Lorca, Granada, Universidad, 1991.

${ }^{4}$ Domínguez Caparrós, José, Diccionario de métrica española, Madrid, Alianza, 2007, p. 61 . 
autor granadino. No obstante, su persistencia apunta claramente a un principio estético que vertebra toda su dramaturgia.

En la canción infantil hay una serie de recursos propios, como las preguntas que sirven para iniciar la canción, las repeticiones (paronomasias, reduplicaciones, geminaciones, anadiplosis, derivaciones, etc.), el encadenamiento, el estribillo, etc. En muchas ocasiones, la repetición en retahíla, de sílabas o palabras y sintagmas completos, está a favor del sinsentido ${ }^{5}$ y del puro juego, en el que el niño demuestra su habilidad apoyándose en estructuras rítmicas. Sucede, por ejemplo, en los trabalenguas, los chistes o las fórmulas de retahíla usadas a veces para echar a suertes. En estos casos, la rima también juega un papel fundamental. Dentro de la variedad de recursos estructurantes de la cantinela y de sus variedades genéricas $^{6}$, cuyos límites muchas veces se confunden, consideraremos especialmente la retahíla y el empleo de la rima.

La zapatera prodigiosa es una de las obras en las que Lorca hace uso frecuente de la cantinela. Precisamente, Andrew A. Anderson afirma que la obra «está enteramente construida con la más extraordinaria colección de expresiones tradicionales jamás oídas en una obra literaria» ${ }^{7}$ y señala la importancia de los géneros dramáticos populares (el entremés, el género chico en general y, en concreto, el sainete) y su relación con las farsas y teatrillos de marionetas

5 Véase el trabajo de Morote Magán, Pascuala, «Juegos de niñas. Entre lo tradicional y lo contemporáneo», en Pedro C. Cerrillo y César Sánchez Ortiz (coords.), La palabra y la memoria (Estudios sobre Literatura Popular Infantil), Cuenca, Ediciones Castilla-La Mancha, 2008, pp. 168-170. Alfonso Reyes se ha referido a estos juegos de palabras sin sentido que rayan en lo absurdo dentro del nombre genérico de jitanjáforas, que serían «meros impulsos rítmicos» y respondería a la «necesidad de oír ciertos ruidos y ciertas pausas». Para Reyes, «la jitanjáfora pura es de carácter popular, y muchas veces infantil» y «se caracteriza en general por su mayor emancipación de los moldes lógicos y lingüísticos». Véase Reyes, Alfonso, La experiencia literaria y otros ensayos, selección y prólogo de Jordi Gracia, Madrid, Fundación Banco Santander, 2009, pp. 195-200 (edición digital: http://www.cervantesvirtual.com/ obra-visor/la-experiencia-literaria-y-otros-ensayos/html/e3575a51-751c-4147-879a62dee2de8ee1_92.html). No hay que olvidar el interés que despertó la jitanjáfora en la Residencia de Estudiantes entre los jóvenes artistas y poetas del 27, entre los que estaba Federico García Lorca. El anaglifo responde igualmente a este sinsentido y se sirve, como la retahíla, de la acumulación absurda.

${ }^{6}$ Véase Cerrillo, Pedro C., «Literatura y juego: las canciones escenificadas infantiles», Revista de Dialectología y tradiciones populares, LIX, 2 (2004), pp. 175-194, recogido en Pedro C. Cerrillo y César Sánchez Ortiz (coords.), La palabra y la memoria..., cit., pp. 135-163, y SilveYRA, Carlos José María, «De la lírica tradicional al folclore infantil», ibid., pp. 117-133.

${ }^{7}$ Anderson, Andrew A., García Lorca. La zapatera prodigiosa, Valencia, Grant \& Cutler, 1991, p. 73. 
lorquianos $^{8}$, donde también hay abundantes canciones y fórmulas orales.

Desde el principio de la obra encontramos canciones populares con estructura en retahíla, caso, por ejemplo, de la cancioncilla siguiente:

Si tu madre quiere un rey,

la baraja tiene cuatro:

rey de oro, rey de copas,

rey de espadas, rey de bastos?.

Son cuatro versos octosílabos de ritmo trocaico con rima asonante en los versos pares. La copla reaparecerá en la versión de 1933 de la obra, pero aquí se refuerza el carácter de canción infantil cuando unas gitanillas amplían estos cuatro versos al añadir una canción de corro:

Si tu madre quiere un rey,

La baraja tiene cuatro:

Rey de oro, rey de copas,

Rey de espadas, rey de bastos.

Corre que te pillo ${ }^{10}$, corre que te agarro, corre que te lleno la falda de barro.

Ábreme la puerta que me estoy mojando...

No me da la gana, ponte chorreando.

Del olivo, me retiro;

del esparto, yo me aparto;

del sarmiento, me arrepiento

de haberte querido tanto.

Corre que te pillo,

${ }^{8}$ Ibid., pp. 23-25. Sobre las versiones y la cronología de La zapatera prodigiosa, puede consultarse el estudio de ANDERSon citado y también el de Devoto, Daniel («Las zapateras prodigiosas», en Andrés Soria Olmedo (ed.), Lecciones sobre Federico García Lorca, cit., pp. 65-78).

9 García Lorca, Federico, Obras Completas, tomo II, Madrid, Aguilar, 1991, pp. 324325. En lo sucesivo se citará por esta edición, indicando la página entre paréntesis junto al texto citado.

${ }^{10}$ La canción recuerda la popular «El patio de mi casa» y, en concreto, su estribillo: «El patio de mi casa / es particular / y cuando llueve mucho / se moja la mitad. / Do re mi. / Do re fa. / Se moja la mitad. / Chocolate. / Molinillo. / Corre, corre, / que te pillo.» En la escena coral de las Lavanderas en Yerma también se evoca, casi al final, esta canción. 
corre que te agarro, corre que te lleno la falda de barro. Ábreme la puerta que me estoy mojando... No me da la gana, ponte chorreando. (pp. 396-397)

Es patente la yuxtaposición entre cancioncillas. A los cuatro primeros versos se añade ahora un romancillo de versos hexasílabos que continúa la rima de los versos anteriores (cuatro, bastos, agarro, barro, mojando, chorreando). Los versos del romancillo son trocaicos también. Incluyo como trocaico, por inercia métrica, «la falda de barro» al entender que la serie trocaica provoca una dislocación del acento de «falda» de la segunda a la tercera sílaba. Estos cambios acentuales son, de hecho, frecuentes en las cantinelas, donde la melodía infantil provoca este tipo de dislocaciones acentuales. La canción continúa con otro grupo de cuatro versos octosílabos que forman una copla también, con la misma rima en -á-o, y que son rematados por el mismo romancillo. Parece evidente la estructura de canción de corro o coral. Originariamente, un grupo recitaría los cuatro primeros versos y el resto el romancillo. La cancioncilla continúa en el diálogo siguiente entre las Gitanillas primera y segunda y la Zapatera. Cambia ahora la rima de la copla, pero el romancillo a modo de estribillo coral se mantiene con variaciones. Lo que nos interesa sobre todo de esta cantinela es la reiteración del ritmo trocaico unida a la reunión y yuxtaposición de versos que no siempre guardan una lógica interna. Así, la copla inicial («Si tu madre quiere un rey...») no tiene nada que ver con el romancillo. E, igualmente, la copla segunda («Del olivo, me retiro...») no guarda vínculo alguno ni con el romancillo ni con la primera copla ni con la siguiente. El procedimiento acumulativo, propio de la canción infantil, es obvio, asimismo, en la rima interna: «del olivo, me retiro», en asonante, «del esparto, yo me aparto» y «del sarmiento, me arrepiento», en consonante. Esta clase de rima interior o interna, que ha recibido diferentes denominaciones según los casos (multiplicado, rima encadenada, versos concatenados por la rima, etc. $)^{11}$, si bien no cumple con la función de reforzar el metro

\footnotetext{
${ }^{11}$ Para una revisión de la rima interna, véase MARTínez, José Enrique, «Los juegos de la rima en un poema de Jaime Siles», Rhythmica, Revista Española de Métrica Comparada, 8 (2010), pp. 97-100.
} 
del verso ${ }^{12}$, sí desempeña un papel de cohesión rítmica y ha sido vista como factor decisivo en la generación del ritmo ${ }^{13}$. A la reiteración contribuyen otros efectos sonoros de repetición, como la anáfora de corre y la aliteración de la vibrante $r$.

A veces es la rima reiterada en palabras alejadas semánticamente la que vertebra la canción infantil. Es lo que aquí sucede y lo que ocurre en otras cantinelas del libro. Sin querer alargar la exposición, recordaremos un ejemplo más, cuando en la escena XI las beatas dicen: «A descansar, maestro, maestrillo, con el mandil amarillo. / A descansar, a descansar; quite, maestrillo, su delantal» (p. 404). Parece claro que la repetición de palabras y las rimas internas son clave en la formulación infantil. El diálogo entre la Zapatera y el niño apunta también en esta misma dirección.

En la cantinela son habituales la rima en eco y las series monorrimas. La rima continuada es, además, especialmente frecuente en Lorca y actúa como factor desencadenante no solamente del ritmo de la cancioncilla, sino como generador de sentido. La niña que riega la albahaca y el príncipe preguntón ${ }^{14} \mathrm{es}$, de acuerdo con el subtítulo, una adaptación teatral de un «viejo cuento andaluz». Desde el principio es ostensible la oralidad popular, con la presencia de pregones y otras fórmulas. Detengámonos en algunos ejemplos que marcan la estructura de la obra. Al inicio de la misma canta el Zapatero:

Zapatero, tero, tero,
iclava la lezna en el agujero!
(p. 62)

En este caso, se trata de un pareado de rima consonante formado por dos versos heterométricos, el primero de ocho sílabas y el segundo de diez sílabas. Hay aquí dos elementos rítmicos que actúan como soportes del pareado y ambos tienen que ver con la

12 Domínguez Caparrós, José, «La rima: entre el ritmo y la eufonía», en Estudios de métrica, Madrid, UNED, 1999, p. 155.

13 Véase FraU, Juan, «La rima en el verso español: tendencias actuales», Rhythmica, Revista Española de Métrica Comparada, 2 (2004), p. 112 y «Rima y estructura del metro», Rhythmica, Revista Española de Métrica Comparada, 9 (2011), pp. 86-98.

14 Sobre la representación de La niña que riega la albahaca y de otras obras en relación con la reivindicación de Falla y de Lorca de los títeres de cachiporra o Cristobitas y de la poesía popular en general, véase HernánDEZ, Mario, «Falla, Lorca y Lanz en una sesión granadina de títeres (1923)», en Dru Dougherty y M ${ }^{\text {a }}$ Francisca Vilches de Frutos (coord. y ed.), El teatro en España entre la tradición y la vanguardia (1918-1939), Madrid, CSIC, Fundación Federico García Lorca, Tabacalera, 1992, pp. 227-239. 
rima: la rima externa en -éro que une ambos versos y, además, la repetición en eco de la rima con la inclusión de la consonante previa: «zapatero, tero, tero». El ritmo binario del primer verso, de claro sentido musical, recuerda las repeticiones corales de los cantares infantiles. Esta cancioncilla con forma de dístico se repetirá con variantes a lo largo de la obra.

El pareado procede de la tradición popular y tiene un contenido sexual obvio. Está incluido en obras previas, como la sainetesca $E l$ señor Luis el Tumbón o Despacho de huevos frescos, de Ricardo de la Vega. Según Margot Versteeg, la aparición de esta clase de canciones populares tenía la función de «crear una atmósfera alegre y propiciatoria de la risa ${ }^{15}$. En el caso de la obra lorquiana, la canción, además, define al personaje y anticipa el núcleo dramático. La cancioncilla reaparece en la Tragicomedia de Don Cristóbal y la señá Rosita. Allí, en el cuadro quinto, mientras hablan Fígaro y Cansa-Almas, un granuja que pasa dice:

¡Zapatero, tero, tero, mete la lezna por el agujero! (p. 137)

En disposición de tercetillo aquí, la repetición de tero sigue marcando el carácter de la canción. El ritmo no vendría dado por los versos, que son heterométricos (octosílabo, pentasílabo y hexasílabo), sino por la rima y por el ritmo trocaico de «zapatero, tero, tero» y «por el agujero». La canción no solamente identificará al personaje del Zapatero ${ }^{16}$, sino, por su matiz sexual, al Príncipe. Por ello, Irene, la hija del Zapatero, utiliza esa rima para dirigirse a él:

IRENE. Dime, rey zaragatero, ¿cuántas estrellitas tiene el cielo? (p. 63)

15 Versteeg, Margot, «El género chico», Diálogos Hispánicos de Amsterdam, 10. Monográfico dedicado a El humor en España, edición al cuidado de Harm den Boer y Fermín Sierra, Ámsterdam, Atlanta, Rodopi, 1992, p. 134. Véase Deleito y PiÑUela, José, Origen y apogeo del género chico, Madrid, Revista de Occidente, 1949. Para otras referencias, véase FuENTES, Tadea, El folklore..., cit., pp. 29-32.

${ }^{16}$ De hecho, el Negro llama al zapatero con el nombre de don Gaiteros y el zapatero dice que, efectivamente, ese es su nombre. Véase FuENTES, Tadea, El folklore..., cit., pp. 168-169. 
Irene sale por vez primera a escena cantando una soleá, pero lo que la identifica más es, además del cantar popular del vito ${ }^{17}$, el diálogo reiterado con el Príncipe. Lorca usa la rima asonante en -á-a y sobre todo la rima en -éro para la confrontación entre ambos personajes:

PRÍNCIPE. Niña que riegas la albahaca, ¿cuántas hojitas tiene la mata?

IRENE. Dime, rey zaragatero, ¿cuántas estrellitas tiene el cielo? (p. 63)

La contraposición de estos dos pareados y de sus variaciones funcionará a lo largo de toda la obra para ilustrar el antagonismo entre Irene y el Príncipe. En el cuento popular, a su vez con distintas variantes, se halla igualmente esta rima y el Príncipe o rey zaragatero, uvatero en la obra lorquiana, pasa a ser un aventurero, un embustero, un encajero o un «pescaero» ${ }^{18}$.

En Los títeres de cachiporra. Tragicomedia de don Cristóbal y la señá Rosita puede comprobarse de nuevo la caracterización de personajes a través de coplillas. El carácter grotesco de Cristobita se vincula a la monstruosidad de ciertos personajes populares a través de sonidos vibrantes y desagradables. En el cuadro segundo, se contrapone a Rosita, que canta el vito, mientras él se asimila al mundo animal con esta canción onomatopéyica de tono infantil:

${ }_{17}$ «Con el vito, vito, vito, / con el vito, vito, va. / Yo no quiero que me miren / que me pongo colorá.» El recuerdo del Vito reaparece en obras posteriores, como la Tragicomedia de don Cristóbal y la señá Rosita o el Retablillo de don Cristóbal. Véase también Cerrillo Torremocha, Pedro y César Sánchez Ortiz, «Presencias y referencias del cancionero infantil en el teatro de García Lorca», Boletín de Literatura Oral, 2 (2019), p. 143.

${ }^{18}$ Hay diversas versiones del cuento. La Universidad de Jaén en su Corpus de literatura oral lo recoge, presentando a un caballero que se disfraza de «pescaero» (corpusdeliteraturaoral.ujaen.es). Véase también M. EsPINosa, Aurelio, Cuentos populares de Castilla y León, tomo II, Madrid, CSIC, 1997; JimÉnez RoMERo, Alfonso, La flor de la flotentena. Cuentos tradicionales, Sevilla, Fundación Machado y Consejería de Educación y Ciencia de la Junta de Andalucía, 1990; RodríGuez Almodóvar, Antonio, «El folklore como huella de un diálogo intercultural perdido (En torno al cuento popular «La niña que riega las albahacas»)», Demófilo, n. ${ }^{\circ} \mathrm{XX}$, Sevilla, 2005, en Pedro C. Cerrillo y César Sánchez Ortiz, La palabra y la memoria..., cit., pp. 59-69. 
¡Bah! Ya la enseñaré a que ponga la voz bronca, ¡más natural!, y cante aquello de

La rana hace cuac, cuac,

cuac, cuac, cuarac ${ }^{19}$.

(p. 122)

Esta intervención, que cierra la escena, es altamente significativa para perfilar al personaje y su asociación con lo animalesco. Cristobita reivindica la naturalidad directa y burda y lo hace utilizando una cancioncilla infantil, donde la onomatopeya y la rima tienen un protagonismo claro. En todos los idiomas son frecuentes estas canciones que enseñan a los niños los sonidos que «hacen» distintos animales y que empiezan siempre por «El perro hace...», «El caballo hace...», «El gato hace...», etc. Lo que verdaderamente importa es la onomatopeya y su repetición rítmica. Lorca ha elegido la rana por estar asociada precisamente al sonido brusco y desagradable que puede caracterizar al personaje. Otras canciones de Cristobita poseen también esta sonoridad fuerte que evoca la violencia de su personalidad. En el cuadro tercero de la obra, cuando llega a la taberna, Cristobita «agarra la porra y canta»:

Que esconda el rabo la zorra, porque le doy con la porra. (p. 129)

Esta aleluya también define completamente al personaje no solamente por el léxico sino por el sonido $r$, recurrente en las cancioncillas de Cristobita. Es importante destacar también que las canciones en boca de este personaje suelen estar formadas por dísticos monorrimos, sea la rima asonante o consonante, lo que da a sus diálogos Cristobita un aire manifiestamente infantil ${ }^{20}$.

El empleo de versos monorrimos heterométricos, donde la rima es el factor estructurante, es frecuente en otras obras. En el Retablillo de don Cristóbal se encuentra a menudo:

${ }_{19}$ Véase Fuentes, Tadea, El folklore..., cit., pp. 13-14.

${ }^{20}$ Margit FrENK destaca la rima pareada en serie y la monorrima como rimas muy frecuentes en la poesía infantil de versos heterométricos. Véase su trabajo «Rimas para juegos infantiles en el antiguo cancionero popular», en Pedro C. Cerrillo y César Sánchez Ortiz (coords.), Presencia del cancionero popular infantil en la lírica hispánica (Homenaje a Margit Frenk), Cuenca, Ediciones de la Universidad de Castilla-La Mancha, 2013, pp. 45-57. 
Me duele el cuello

donde me nace el cabello, pero no había caído en ello hasta que me lo dijo mi primo Juan Coello. (p. 680)

Y, más adelante, hay otra serie monorrima con rima en -íto (y su plural -ítos), diminutivo que sugiere claramente la filiación infantil:

Veinte duritos y veinte duritos,

y debajo del chalequito

seis duritos y tres duritos,

y en el ojito

del culito

tengo un rollito

con veinte duritos.

(p. 682)

Otros muchos pasajes muestran este tipo de rima continuada, bien en pareados, bien en versos en serie. El juego infantil no solamente se asocia a la rima, sino a la técnica de la retahíla. También en el Retablillo de don Cristóbal leemos en boca de Rosita:

En esta hora los niños cuentan las estrellas y los viejos se duermen sobre sus caballos, pero yo quisiera estar:

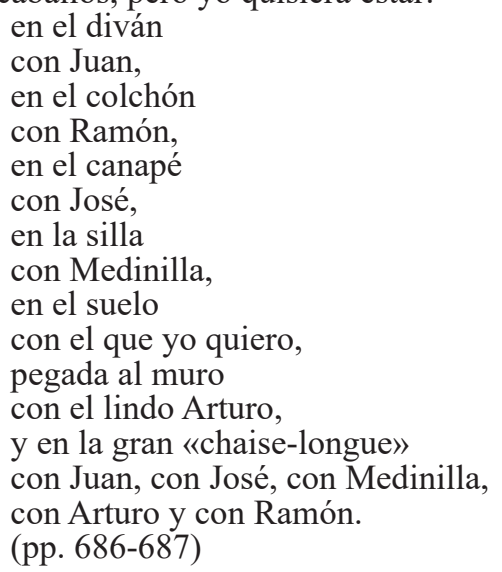

E inmediatamente después, recrea Rosita una cantinela ya inserta en La zapatera prodigiosa: 
Yo me quiero casar, ¿me han oído?

Yo me quiero casar con un mocito, con un militar, con un arzobispo, con un general, con un macanudo de macanear y veinte mocitos de Portugal. (p. 687)

Es una canción de rueda ${ }^{21}$ en retahíla que utiliza la rima alterna, asonante y consonante, y deja algún verso suelto. Lo importante es la acumulación rítmica de estos versos heterométricos y la rima. La retahíla se retomará un poco más adelante, cuando Rosita declara:

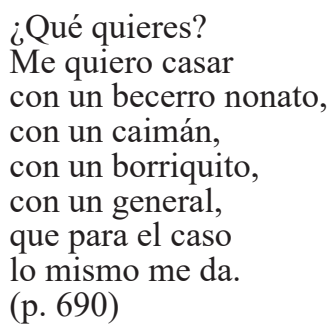

La retahíla no solamente se halla en farsas y obras guiñolescas, sino en el teatro trágico lorquiano. Así ocurre en el cuadro último de Bodas de sangre, cuando dos muchachas, que visten de azul oscuro y devanan una madeja roja, intervienen asumiendo la función de coro con la técnica de las canciones populares y los encadenamientos de la retahíla que la madeja simboliza. Como explica Ricardo Doménech, «a la madeja se le formulan una serie de preguntas, a las que corresponderán otras tantas respuestas enigmáticas» ${ }^{22}$ :

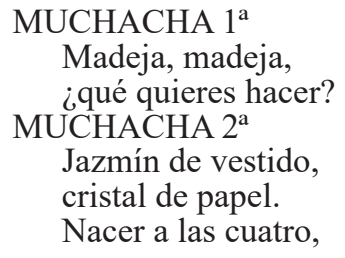

$\overline{{ }^{21}}$ Véase FuEnTES, Tadea, El folklore..., cit., pp. 133-134.

22 Doménech, Ricardo, García Lorca y la tragedia, Madrid, Fundamentos, 2008, p. 82. 
morir a las diez.

Ser hilo de lana, cadena a tus pies y nudo que apriete amargo laurel.

(p. 788)

La canción y el diálogo entre las muchachas continúan a lo largo de toda la escena. Baste este fragmento para ilustrar el procedimiento acumulativo eslabonado. Se trata, como otras composiciones populares, de una estructura que, al igual que otros poemas corales, se concibe de manera circular y cuyo símbolo sería la rueda, la ronda, la corona o la madeja ${ }^{23}$.

En La casa de Bernarda Alba vuelve Lorca a servirse de la canción popular en varios pasajes. El personaje que se identifica con la cantinela infantil y que queda caracterizado a través de ella es la madre de Bernarda, María Josefa. Es un personaje que guarda cierta relación con la figura del Pastor Bobo de El público. Ambos, por bobos o locos, son sabios y poseen una dimensión crítica y reveladora de la verdad oculta. María Josefa entra en escena en el acto III con una oveja en brazos y canta una copla inicial, una nana, de versos heterométricos con rima asonante. Pero después se yuxtapone a esta nana una canción infantil, organizada en dísticos, los dos primeros con rima consonante y el último con rima asonante. Es nuevamente la rima lo que da unidad formal a estos versos irregulares, así como la composición en retahíla propia de la cantinela. La misma estructura se reitera inmediatamente después, al seguir otra copla heterométrica -otra nana- rematada por la retahíla anterior:

Ovejita, niño mío,

Vámonos a la orilla del mar.

La hormiguita estará en su puerta,

Yo te daré la teta y el pan.

Bernarda,

cara de leoparda.

Magdalena,

cara de hiena.

¡Ovejita!

Meee, meeee.

Vamos a los ramos del portal de Belén.

23 Ibid. Véase Correa, Gustavo, La poesía mítica de Federico García Lorca, Madrid, Gredos, 1970, p. 106. 
Ni tú ni yo queremos dormir;

la puerta sola se abrirá

y en la playa nos meteremos

en una choza de coral.

Bernarda,

cara de leoparda.

Magdalena,

cara de hiena.

¡Ovejita!

Meee, meeee.

Vamos a los ramos del portal de Belén.

(pp. 1056-1057)

La ingenuidad de María Josefa es, como se aprecia en sus intervenciones, una ingenuidad formal, fundamentada en el manejo infantil y en retahíla de la rima. En el juego infantil «Bernarda, / cara de leoparda...», los versos pareados forman eneasílabos, salvo el último que es un tridecasílabo. El verso quinto y el sexto («iOvejita! / Meee, meeee») son, en realidad, un mismo verso eneasílabo, dividido tipográficamente para dar mayor protagonismo a la ovejita-niño y a la onomatopeya imitativa del balar de la oveja: la rima final (-é, de Meeee y de Belén) confirma que sigue operando el modelo del dístico de los versos anteriores. El juego infantil de la rima asociada a cada personaje continúa un poco más adelante. Cuando Martirio insta a su abuela, María Josefa, a que se acueste, esta le contesta: «Tú eres Martirio, ya te veo. Martirio, cara de Martirio. ¿Y cuándo vas a tener un niño? Yo he tenido este.» (p. 1057)24. Después María Josefa continúa haciendo uso de la rima en palabras que evocan otra vez las rimas continuadas de los versos infantiles.

Lorca se sirve también de la cantinela en su etapa surrealista. En contra de lo que pudiera pensarse, los juegos infantiles se ajustan muy bien al procedimiento de reunión caleidoscópica de imágenes de la estética vanguardista. Recuérdese, sin más, el interés por la jitanjáfora o el anaglifo. Así, en el teatro surrealista de Lorca hay también retahílas ligadas a la rima y a la canción infantil. Y, a menudo, las cantinelas tienen una función clave en la creación de los personajes. Así sucede, por ejemplo, en el Acto I de Así que pasen cinco años, cuando aparecen el Niño y el Gato. En la escena, en verso, se emplea la rima de romance -á-a y se utilizan coplillas

\footnotetext{
${ }^{24}$ Pedro Cerrillo Torremocha y César SÁnchez Ortiz comentan que «en el Cancionero Infantil son varios los ejemplos de burlas que se dicen a personas, por razón de su nombre propio.» («Presencias y referencias...», cit., p. 144).
} 
en las que se pone de manifiesto la técnica acumulativa de la rima, como es evidente en una de las intervenciones del Gato:

Iba por tejado, gata chata ${ }^{25}$,

naricillas de hojadelata,

en la mañana

iba a recoger los peces por el agua

y al mediodía

bajo el rosal del muro me dormía.

(p. 517)

En esta canción los versos son heterométricos (endecasílabo, eneasílabo, pentasílabo, dodecasílabo), por lo que puede decirse que su estructura rítmica no reside en absoluto en la regularidad métrica. No obstante, existen otras bases rítmicas. Entre ellas, sobresale la rima, asonante y consonante, que se presenta tanto de forma externa, esto es, a final de verso, como de forma interna, como rima en eco. Ya desde el principio, se observa la reiteración algo machacona de -áta, con la rima en eco de «gata chata». Los versos se organizan como pareados, los dos primeros con rima consonante y los dos segundos con rima asonante tanto entre ellos como con los anteriores. Y, luego, en los dos últimos cambia la rima a -ía. En el diálogo que sigue, la rima de -áta vuelve de nuevo, combinada con la retahíla, en otra intervención, esta vez en boca del Niño y con versos de ritmo endecasilábico (alejandrino, eneasílabo, endecasílabos y heptasílabo):

Yo también iba, jay!, gata chata, barata, naricillas de hojadelata, a comer zarzamoras y manzanas

y después a la iglesia con los niños

a jugar a la cabra.

(p. 518)

El diálogo en verso continúa con rima asonante y, más adelante, el Niño se sirve otra vez de la retahíla, con versos octosílabos y rima de romance:

25 Daniel Devoto ve aquí el eco de las aleluyas infantiles «Chata barata, narices de gata», que sería un «dicho popular, con que se trata de molestar e impacientar a la persona que tiene aquel defecto.» («Notas sobre el elemento tradicional...», cit., p. 70). Véase FuENTES, Tadea, El folklore..., cit., pp. 128-130. 
Vámonos; de casa en casa

llegaremos donde pacen

los caballitos del agua.

No es el cielo. Es tierra dura

con muchos grillos que cantan,

con hierbas que se menean,

con nubes que se levantan,

con hondas que lanzan piedras

y el viento como una espada.

¡Yo quiero ser niño, un niño!

(p. 520)

Desde el verso quinto, la yuxtaposición o retahíla de elementos (con muchos grillos, con hierbas, con nubes, con hondas, y el viento) articula la cantinela, apoyándose, asimismo, en la anáfora, el paralelismo y el ritmo de los versos octosílabos, muchos de ellos de base trocaica. Son rasgos decisivos en la evocación de las canciones infantiles. El verso «con nubes que se levantan» es, además, intertexto de «las nubes se levantan», de otra cancioncilla popular de corro $^{26}$.

Más adelante, vuelven el Niño y la Gata sobre la cantinela en retahíla, usando la figura retórica de la anadiplosis para enlazar la canción del Niño y la canción que, inmediatamente después, canta este con la Gata. El sintagma «y en el pico una flor» actúa en la intervención del Niño como nuevo intertexto de otra canción popular que quedará interrumpida:

NIÑO

Apagado va por el cielo.

Solo mares y montes de carbón, y una paloma muerta por la arena con las alas tronchadas y en el pico una flor.

(Cantan.)

$\mathrm{Y}$ en la flor una oliva, y en la oliva un limón...

¿Cómo sigue?... No lo sé, ¿cómo sigue?27

${ }_{26}$ "Que llueva, que llueva, / la virgen de la cueva, / los pajaritos cantan, / las nubes se levantan... / Que sí, que no, / que caiga un chaparrón / con azúcar y turrón / Que se rompan los cristales de la estación.» Véase para esta canción MARTOS NúÑEZ, Eloy, «Canciones infantiles y leyendas sobre tormentas», en Pedro C. Cerrillo y César Sánchez Ortiz, Presencia del cancionero..., cit., p. 238.

27 A propósito de estos versos, Daniel Devoto («Notas sobre el elemento tradicional...», cit., p. 70) recalca que la fuente es la canción de la Pájara pinta. Véase también FuENTES, Tadea, El folklore..., cit., pp. 100-102. 
GATA NIÑO

¡Ay girasol!

¡Ay girasol de la mañanita!

¡Ay clavelina del sol!

(p. 521)

La rima en -ó y -ón en los pares, o rima de romance, es la que sirve de fundamento rítmico de los versos, a lo que se añade la heterometría predominantemente endecasilábica, con varios versos endecasílabos y heptasílabos, un verso alejandrino, un eneasílabo, un decasílabo y un octosílabo. Es fundamentalmente la rima el elemento estructurante de estos versos. En todo caso, la forma en retahíla, interrumpida por el olvido de lo que sigue por parte de los personajes («¿Cómo sigue?... No lo sé, ¿cómo sigue?»), es otro factor relevante en el diálogo y las cancioncillas del Niño y de la Gata. La aparición de cantinelas en Así que pasen cinco años guarda relación, sin duda, con el trasmundo de la muerte y los sueños. Por ese motivo, el Niño y la Gata muertos retoman estas cancioncillas del pasado, como lo harán también, en el cuadro primero del Acto tercero de la obra, con la recreación de otra copla popular, el Arlequín y la Muchacha, figuras ligadas a la muerte y al misterio de lo oculto.

En El público la cantinela tiene una importante carga semántica y estructural. Como muestra, mencionaremos la canción del Caballo Blanco 1 y sus variantes del cuadro tercero, que puede interpretarse como canción coral contrapuntística respecto de los diálogos de los personajes. El carácter infantil de esta cancioncilla se debe al juego paronomásico de los versos primero y segundo, a las aliteraciones, a las repeticiones (anáfora, anadiplosis) y a la rima, interna y externa. Nuevamente, se mezcla rima asonante y consonante, con tres versos monorrimos (-ó) a los que se suma un pareado de rima asonante en -á. Hay que añadir, además, que los versos segundo y tercero evocan la cancioncilla infantil en la que los niños llaman al caracol, usando también la reiteración de la rima, para que salga al sol tras la lluvia ${ }^{28}$.

$\overline{28}$ Véase Frenk, Margit, «Rimas para juegos infantiles...», cit., p. 43. Cuenta Rafael MARTÍNEZ NADAL lo siguiente: «En Cuenca, Carlos Morla, Federico y yo, oímos a unas niñas que buscaban caracoles después de la lluvia entonar:

Caracol, col, col, saca los cuernos al sol, que tu padre y tu madre también los sacó. 
Amor. Amar. Amor.

Amor del caracol, col, col, col, que saca los cuernos al sol.

Amar. Amor. Amar.

Del caballo que lame la bola de sal.

(p. 631)

Los versos son heterométricos, aunque predomina la base heptasilábica que marca el primer verso y que se repite en el segundo y el cuarto. En el segundo verso la reiteración de la rima («col, col, col»), con inclusión de la consonante anterior al acento versal, alarga el verso de las siete a las diez sílabas. La estructura rítmica de los versos es yámbica en los dos primeros y en el cuarto, mientras que los versos tercero y quinto tienen ritmo ternario, anfibráquico y anapéstico, ritmo ternario que refuerza la similitud entre «que saca los cuernos al sol» y «que lame la bola de sal». Más interesante es la conexión semántica con la obra, en la que el juego de espejos, máscaras e identidades amorosas y eróticas tiene aquí una manifestación en la repetición y la paronomasia y poliptoton entre «amor» y «amar» (también entre «sol»y «sal»). La rima en eco refuerza esta idea, así como la variación complementaria entre el caracol que sale con sus cuernos y el caballo que lame la bola de sal, ambas imágenes animalescas de evidente contenido erótico.

La canción se repite en la escena con variantes que revelan más claramente la funcionalidad rítmica de estos elementos formales y que también ponen de manifiesto que el procedimiento acumulativo de la retahíla está funcionando como medio de yuxtaposición de imágenes que se hacen entre sí semánticamente equivalentes. Si antes el caballo y el caracol se complementaban, se suman en las variaciones siguientes otros personajes (y también otras metamorfosis amorosas) que ilustran el concepto del amor lorquiano.

La técnica de la retahíla y el uso de la rima continua, asociada, como se ha dicho ya, al juego infantil, reaparecen en El público

Los dos últimos versos, violenta deformación de las múltiples versiones que existen del

caracol, col, col

saca los cuernos y vete al sol.

«Formulilla con que los niños pretenden obligar al caracol a hacer lo que en ella se dice». (Torner, Eduardo M., Lírica hispánica, Madrid, Castalia, 1966, p. 113).

«Con pluralidad de sentidos -erótico uno de ellos- utilizan también esa «formulilla» varios poetas del Siglo de Oro». (Martínez Nadal, Rafael, «El público». Amor y muerte en la obra de Federico García Lorca, Madrid, Hiperión, 1988, nota 24, p. 298). Véase Fuentes, Tadea, El folklore..., cit., pp. 202-203. 
en boca del Pastor Bobo, personaje que, con un estilo y tono pueriles, desvela las claves semánticas de la obra ${ }^{29}$. A este respecto, Javier Huerta Calvo señala que el lenguaje de la canción del Pastor Bobo es «irracional e infantilizado, salpicado de ripios y palabras inventadas, es un eco del cómico sayagués que chamullaban los rústicos de Encina o Fernández» ${ }^{30}$.

En el llamado Solo del Pastor Bobo, la cohesión rítmica no viene dada por la igualdad silábica de los versos. La heterometría es evidente, por más que, en ocasiones, varios versos seguidos reiteren el número de sílabas. Pero lo que sí aparece regularmente, salvo en dos versos, es la rima generalizada en -éta(s). La canción se fundamenta en la acumulación de elementos en retahíla (las sucesivas caretas de los pordioseros, de los poetas, de los niños, de las águilas, de la careta, etc.) y el recurso de la rima del diminutivo en - eta, rima externa pero también interna («careta de la careta, / que era de yeso de Creta»). Y a esto se añaden otros recursos retóricos de repetición, como la anadiplosis o la anáfora. En la escena, el Pastor Bobo toca un aristón y danza con ritmo lento, con lo que se presupone el acompañamiento musical. El carácter popular del personaje no solamente tiene que ver con los bobos de la tradición teatral sino con los músicos y titiriteros ambulantes:

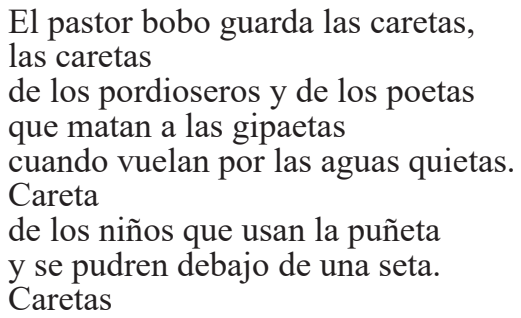

${ }^{29}$ Algunos críticos han puesto de manifiesto la filiación de este personaje con el teatro de Gil Vicente o Torres Naharro. La escena, como señalaron tempranamente Rosana Vitale y Ana María Gómez ToRres, debiera estar al principio de la obra, como introito que revela la clave metateatral de la misma. Véase Vitale, Rosana, El metateatro en la obra de Federico García Lorca, Madrid, Pliegos, 1991, y Gómez Torres, Ana María, Experimentación y teoría en el teatro de Federico García Lorca, Málaga, Arguval, 1995, pp. 37-43, y «Procedimientos teóricos y ruptura de la mímesis clásica en el teatro de Lorca», en Cristóbal Cuevas García (ed.), El teatro de Lorca. Tragedia, drama y farsa, Málaga, Publicaciones del Congreso de Literatura Española Contemporánea, 1995, pp. 94-97. Véase también HuERTA CaLvo, Javier, «Introducción» a Federico García Lorca, Teatro completo, edición del Instituto del Teatro de Madrid, dirigida por Javier Huerta Calvo y al cuidado de Sergio Santiago Romero y Javier Domingo Martín, Madrid, Verbum, 2019, pp. 21-22.

${ }^{30}$ Ibid., p. 22. 
de las águilas con muletas.

Careta de la careta

que era de yeso de Creta

y se puso de lanita color violeta

en el asesinato de Julieta.

Adivina, adivinilla, adivineta,

de un teatro sin lunetas

y un cielo lleno de sillas

con el hueco de una careta.

Balad, balad, balad, caretas.

Los caballos se comen la seta

y se pudren bajo la veleta.

Las águilas usan la puñeta

y se llenan de fango bajo el cometa.

Y el cometa devora la gipaeta

que rayaba el pecho del poeta.

¡Balad, balad, balad, caretas!

Europa se arranca las tetas,

Asia se queda sin lunetas

y América es un cocodrilo

que no necesita careta.

La musiquilla, la musiqueta

de las púas heridas y la limeta.

(pp. 662-663)

Es el poeta, aquí convertido en Pastor Bobo, quien reflexiona sobre el problema central de la identidad personal, de ahí el valor asociativo de la rima: el poeta y sus caretas en la disyuntiva social y amorosa. La palabra generadora de la rima es «careta» y su plural (poliptoton, «careta»-«caretas»). Lorca va alternando la rima consonante en -étas y en -éta e intercala por dos veces la apelación a las caretas con el estribillo «Balad, balad, balad, caretas», donde la geminación del verbo favorece el aire de cantinela. También hay geminación en forma de derivación en el verso «adivina, adivinilla, adiveneta» y en «la musiquilla, la musiqueta». Por otra parte, el diminutivo en -éta $(s)$, de carácter burlesco, refuerza el tono de juego infantil de la composición, en palabras como «puñeta», «luneta», «adivineta», «musiqueta». Contribuye también al carácter infantil el neologismo de «gipaetas», palabra reiterada luego en singular, en alusión a «gypaetus barbatus» o simplemente a las «águilas con muletas» del verso décimo. La imagen de la gipaeta muerta, del águila con muleta y la reaparición del término asociado al pecho del 
poeta en el verso vigésimo quinto sugieren la identificación entre el poeta y su identidad escondida, que él mismo destruye o que destruye el cometa («y el cometa devora la gipaeta»). Sin entrar ahora en un análisis interpretativo de los vocablos usados (imágenes del poeta y del hombre), parece evidente que la reunión de términos y la reiteración rítmica de la rima se convierten en elementos estructurantes del sentido textual. De este modo, es el rasgo formal sonoro de la rima el que cohesiona la retahíla y otorga unidad rítmica a los $\operatorname{versos}^{31}$. Así, bajo la apariencia del sinsentido infantil que juega con la agrupación de palabras e imágenes en retahíla, esa acumulación lúdica está precisamente a favor del desvelamiento de la identidad y se convierte entonces en motor estructural y semántico del texto.

Conviene recordar que en el surrealismo son frecuentes las yuxtaposiciones metafóricas y tropológicas, como ya vio muy acertadamente Riffaterre. Se trata, en realidad, de un uso vivo de la metáfora $^{32}$. Pero aquí las imágenes metafóricas están vinculadas e impulsadas en su devenir por la rima. Por tanto, no se trata de una rima simple, sino de una rima unificadora y reveladora de sentido, por la que se generan las palabras y por la que los distintos términos y sus imágenes asociadas son facetas (o espejos) de un mismo concepto. Puede hablarse, por lo tanto, no solo de metáforas e imágenes hiladas, a la manera surrealista, sino también de rima hilada, creadora y generatriz, que, bajo un aparente sinsentido de raíz popular, nos ofrece las claves temáticas de la obra.

${ }_{31}$ Este contraste entre coherencia formal e inconsecuencia lógica ha sido destacado por Benoît DE CORNULIER en el estudio de algunas canciones francesas ("Quelques chansons de (non?) travail (La Fontaine, Rimbaud, des enfants)», p. 5, en red: http://www. normalesup.org/ bdecornulier/).

32 Véase Ricoeur, Paul, La metáfora viva, Buenos Aires, Megápolis, 1982, y RifFATERre, Michael, "La métaphore filée dans la poésie surréaliste», Langue Française. La Stylistique, 3 (1969), pp. 46-60. 